\section{SCORECARD}

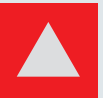

ving the planet

NASA's planetary protection officer, John

Rummel, is leaving. His two main tasks: protecting other planets from contamination by us, and protecting us from alien life. Seems he had a perfect record.

\section{Golden age}

Entrepreneur Peter Thiel has pledged US $\$ 3.5$ million to researcher Aubrey de Grey to pursue his theory that people can live indefinitely. But de Grey reckons he needs $\$ 1$ billion.

\section{ZOO NEWS}

\section{Cosy penguins}

Up to 2,000 fibreglass igloos are being built to house endangered penguins on Dyer Island in South Africa. But it's not ice the birds are missing - it's guano. The penguins use it for nests, but since the 1970s humans have been harvesting it for fertilizer.

\section{Chainsaw reaction} In February, a US agency announced that it was mapping the habitat of an endangered woodpecker around Boiling Spring Lakes in North Carolina. The move could subject areas of the town to more stringent building restrictions. Landowners have responded by felling thousands of trees to drive the woodpecker out.

\section{ON THE RECORD}

\section{"It won't stop until some of these scientists are dead."}

Climatologist James Hansen sees a slow end to climate scepticism.

\section{NUMBER CRUNCH}

14 shuttle flights are needed in the next four years to finish the International Space Station.

19 shuttle flights were achieved in the four years between 1988 and 1991, when NASA also had three operational shuttles.

3 shuttle flights have taken place in the past three years.

\title{
Bad Boys question received wisdom on HIV
}

HIV is a frustrating foe, but at least doctors have been able to count on a few solid principles to help them fight the virus. Now, a group of scientists calling itself 'The Bad Boys of Cleveland' reports evidence that rebels against one of those principles. The findings cement a feeling that has been growing in the HIV research community: that the virus enlists patients' own defences to dismantle their immune systems.

This revises the picture first painted a decade ago, when studies reported that levels of HIV in a patient's blood predict how fast the patient will lose vital T cells. Since then, doctors have believed that the virus is the main trigger for T-cell loss. They rely on measurements of viral load to help them decide when and how to treat patients with HIV.

But it is increasingly clear that virus levels are only a small part of the story. In fact, as Benigno Rodriguez of Case Western Reserve University in Cleveland reports this week, viral load explains only $4-6 \%$ of the rate at which a patient's T cells disappear (B. Rodriguez et. al. J. Am. Med. Assoc. 296, 1498-1506; 2006).

Rodriguez and his collaborators in California, Massachusetts and Washington examined blood samples from thousands of patients dating from 1984. They analysed the patients' viral load and T-cell count before treatment with
"We've been doing this on a shoestring people pay their own air fare. They come because they like the atmosphere." antiretroviral drugs. The group found that, in general, patients with higher viral loads lost their $\mathrm{T}$ cells faster than those with lower virus levels. But the disease progressed at different rates in patients with similar viral loads. This suggests that something other than virus levels alone is driving T-cell loss.

Now, scientists must find out what that is. Many suspect that a phenomenon called immune activation is an important factor. This is the idea that HIV whips the body's immune system into a frenzy, and that this flurry of activity eventually triggers T-cell death. "This paper will help shift the focus of basic research to immune activation," says immunologist Zvi Grossman of the US National Institutes of

\section{Mouse brain map is complete}

Three years, 21,000 genes and US\$41 million after the Allen Brain Atlas was begun, it is finished. A three-dimensional map of gene expression in the mouse brain, the atlas is the most comprehensive study of its kind to date.

A personal interest in neuroscience saw Paul Allen, the billionaire philanthropist who co-founded Microsoft, establish the Allen Institute for Brain Science in Seattle, Washington, in 2001. He donated $\$ 100$ million: half went on the Brain Atlas, launched in 2003 as the institute's first major project after two years of consultation.

Researchers mapped where each of the mouse brain's 21,000 genes are expressed by staining brain sections with probes specific to each gene. The resulting atlas provides insight into the brain's function, helping researchers understand how different regions operate and interact. Allan Jones, chief

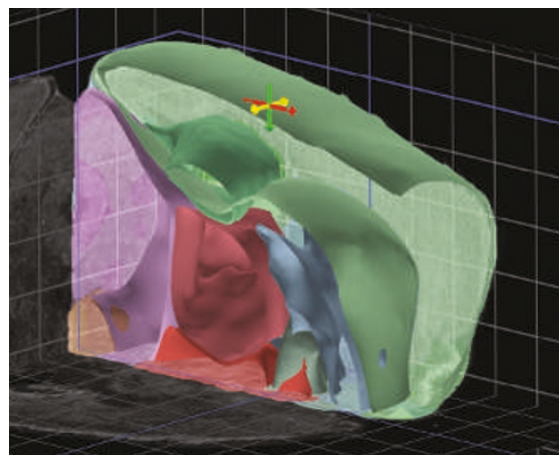

scientific officer at the Allen Institute, is confident that the atlas will "dramatically propel neuroscience forwards".

The atlas is available free of charge online in the form of a database. Users can search for particular genes, then scroll through
Computergenerated cutaway of a mouse brain from Allen Brain Atlas data. 